Journal of

HIV/AIDS \& Infectious Diseases

\title{
Guillain Barre Syndrome in AIDS Patient Secondary to An Acute and Confirmed Hepatitis C Virus
}

\author{
Aude Belbézier ${ }^{1 *}$, Annick Bosseray ${ }^{1}$, Barbara Colombe ${ }^{1}$, Alexis Bocquet ${ }^{1}$, Catherine Mansard ${ }^{1}$, Vincent Leroy ${ }^{2}$, \\ Pascal Leclercq ${ }^{3}$ and Laurence Bouillet ${ }^{1}$
}

${ }^{1}$ Department of Internal Medicine, Grenoble University Hospital, Grenoble, France

${ }^{2}$ Department of Hepatology, Grenoble University Hospital, Grenoble

${ }^{3}$ Department of Emergency, Grenoble University Hospital, Grenoble

${ }^{\star}$ Corresponding author: Aude Belbézier, Clinique universitaire de médecine interne, Pôle pluridisciplinaire de médecine, Centre hospitalier universitaire de Grenoble, CS10217, 38043 Grenoble cedex 09 France; Tel: 33-476-765-513; Fax: +3376765816, E-mail: abelbezier1@chu-grenoble.fr

Received Date: January 05, 2019; Accepted Date: February 13, 2019; Published Date: February 18, 2019

Citation: Aude Belbézier (2019) Guillain Barre Syndrome in AIDS Patient Secondary to An Acute and Confirmed Hepatitis C Virus. J HIV AIDS Infect Dis 5: 1-3.

\begin{abstract}
A 73-AIDS year-old man presented an acute distal sensitive motor deficiency. Electromyogram showed a Guillain-Barre Syndrome. Diagnosis work-up revealed an acute hepatitis $\mathrm{C}$ with detectable viral load in cerebrospinal fluid and serum. The patient was treated with HCV direct anti-viral agents and immunomodulatory therapies and fully recovered from neurologic symptoms.

Keywords: Prevention of Mother to Child Transmission, HIV/AIDS, Knowledge, Attitude, Practice, Hosanna, South Ethiopia
\end{abstract}

\section{Letter to the Editor}

Hepatitis $\mathrm{C}$ virus $(\mathrm{HCV})$ is a known trigger of dys immune disease such as cryoglobulinemia. When these two diseases are associated, peripheral neurological manifestation could appear. Without this association, the role of HCV as a cause of neurological manifestation is still unclear [1]. We report a case of Guillain-Barré Syndrome (GBS) associated with acute HCV infection.

A 73-year-old man was hospitalized for sudden weakness of the lower limbs. He had a medical history of acquired human immunodeficiency virus (AIDS) infection treated and controlled (undetectable viral load, $0.320 \mathrm{G} / \mathrm{L}$ CD4 cells) with Prezista, Norvir, Emtricitabine, Tenofovir therapy and a sclerosing cholangitis by cytomegalovirus. Physical examination revealed a motor weakness on lower limbs and absence of patellar deep tendon reflexes. Sensory

(C)2019 The Authors. Published by the JScholar under the terms of the Creative Commons Attribution License http://creativecommons.org/licenses/by/3.0/, which permits unrestricted use, provided the original author and source are credited. testing showed a hypoesthesia on lower limbs, associated with a sensitive ataxia. Laboratory tests performed on admission showed elevated liver tests (conjugated bilirubin $17 \mu \mathrm{mol} / \mathrm{L}$ $(\mathrm{N}<30)$, aspartate-amino transferase $187 \mathrm{UI} / \mathrm{L}(\mathrm{N}<37)$, alanine amino transferase $259 \mathrm{UI} / \mathrm{L}(\mathrm{N}<78)$, gamma-glutamyl transpeptidase $381 \mathrm{UI} / \mathrm{L}(\mathrm{N}<246)$, alkaline phosphatase 115 $\mathrm{UI} / \mathrm{L}(\mathrm{N}<126)$ ) associated with a lymphopenia (lymphocyte $0.8 \mathrm{G} / \mathrm{L}$ with $0.320 \mathrm{G} / \mathrm{L} \mathrm{CD} 4)$. Test results were within reference ranges for calcium, creatinine, albumin, glycemia, C- reactive protein, prothrombin time, thyroid-stimulating hormone, B9 -, B12- vitamins, hepatitis B virus, Epstein Barr virus, human T-lymphotropic viruses 1 and 2, Treponema pallidum, Borrelia burgdorferi, Toxoplasma gondii.

Serologic testing for cytomegalovirus showed previous exposure. Serum samples were positive for $\mathrm{HCV}$ IgG (index 7.6 MONOLISA kit, 8 ARCHITECT), while it was negative five months before. HCV RNA was detected in serum samples at 1.57 logs by using HCV polymerase chain reaction (PCR) on COBAS Ampliprep/Taqman system 
(Roche Diagnostics, Mannheim, Germany). Sequencing studies showed that the HCV strain belonged to genotype 1a. Cerebrospinal fluid (CSF) analysis showed an elevated protein concentration $(238 \mathrm{mg} / \mathrm{dl})$ without cellular response and HCV viral load at 1,57 log (using HCV PCR on COBAS Ampliprep/ Taqman system). HIV viral load on CSF was negative.

Nerve conduction studies showed findings compatible with GBS. Test for anti-gangliosides antibodies (GM1, GM2, GD1A, GD1B, GT1A, GT1B (using Ganglio Combi ELISA test (Bühlmann, Schönenbuch, Switzerland)) were negative. Given this association of $\mathrm{HCV}$ infection and GBS, research for cryoglobulinemia was performed but was negative. A diagnosis of GBS with HCV was done, and intravenous immunoglobulin (IVIg) treatment $(2 \mathrm{~g} / \mathrm{kg}$ ) was administered associated with antiviral HCV therapy including Sofosbuvir $400 \mathrm{mg} / \mathrm{d}$ and Daclastavir $60 \mathrm{mg} / \mathrm{d}$ for 12 weeks. With this treatment he fully recovered from neurologic symptoms (which is frequent in GBS), ALT and AST levels returned to normal and HCV RNA became negative in serum. The patient achieved a sustained virological response, with HCV RNA not detectable neither in serum nor in CSF 12 weeks after the end of antiviral treatment. We described here a case of acute HCV infection associated with GBS with positive HCV CSF viral load occurring in an HIV-infected patient.

Neurotropism of HCV was described shortly after the discovery of this virus in 1989 [2]. Few cases of peripheral chronic neuropathy including sensorimotor, small fibber sensory- or motor-polyneuropathy and autonomic neuropathy secondary to chronic HCV have been described [3]. These cases were often associated with cryoglobulinemia [4], and in some cases, with anti-MAG antibodies [4]. However acute neuropathy was infrequent. In fact, only 2 cases of GBS have been previously described associated with HCV infection [5, 6]. We also presented the third case which was here associated with acute HCV infection. In one of the described cases [5], HCV- infection was likely to be acute because of the rapidly and consistent normalization of liver enzymes after an episode of increment. However, HCV serology was not performed before which could not permit draw definitive conclusion.

According to the neurotropism of this virus, its potential role as a trigger is suspected. Even though the presence of the virus in central nervous system is described $[7,8]$ in central neurological disorders, it is not exact for peripheral neurological syndromes. Indeed, in spite of a few cases of HCV infection associated with neuropathy, his potential role as a trigger has always been debated when it is not associated with mixed cryoglobulinemia because of the absence of the $\mathrm{HCV}$ virus on nerve biopsy. HCV RNA has rarely been searched on CSF, however, one reported case with $\mathrm{HCV}$ viral load on CSF [7]. The role of cryoglobulinemia is less debated because of its association with neuropathy in other diseases like myeloma [9] and the presence of neurons damage in cryoglobulinic patient's $[1,10]$.

\section{Conclusion}

The presence of positive HCV RNA in CSF of our patient without immunodepression, cryoglobulin nor other viral neurological coinfection could give an argument of role of $\mathrm{HCV}$ as a trigger in GBS. However, a causal relationship between $\mathrm{HCV}$ and peripheral neuropathy could not be completely ascertained. The research in peripheral neuropathy of HCV RNA in CSF could be interesting to study to prove this association.

\section{References}

1. Cashman CR, Höke A. (2015) Mechanisms of distal axonal degeneration in peripheral neuropathies. Neurosci Lett. 596:33-50.

2. Authier FJ, Pawlotsky JM, Viard JP, Guillevin L, Degos JD, Gherardi RK. (1993) High incidence of hepatitis C virus infection in patients with cryoglobulinemic neuropathy. Ann Neurol. 34:749-50.

3. Adinolfi LE, Nevola R, Lus G, Restivo L, Guerrera B, Romano C, et al. (2015) Chronic hepatitis C virus infection and neurological and psychiatric disorders: an overview. World J Gastroenterol. 21:2269-80.

4. Mariotto S, Ferrari S, Monaco S. (2014) HCVrelated central and peripheral nervous system demyelinating disorders. Inflamm Allergy Drug Targets. 13:299-304.

5. Klippel ND, Hautekeete ML, Keyser JD, Ebinger G. (1993) Guillain-Barré syndrome as the presenting manifestation of hepatitis $\mathrm{C}$ infection. Neurology. 43:2143-2143.

6. Lacaille F, Zylberberg $H$, Hagège $H$, Roualdès B, Meyrignac C, Chousterman M, et al. (1998) Hepatitis C associated with Guillain-Barré syndrome. Liver. 18:49-51.

7. Bagaglio S, Cinque P, Racca S, Pedale R, Grasso MA, 
Lazzarin A, et al. (2005) Hepatitis C virus populations in the plasma, peripheral blood mononuclear cells and cerebrospinal fluid of HIV/hepatitis C virus-co-infected patients. AIDS. 19:S151-165.

8. Laskus T, Radkowski M, Adair DM, Wilkinson J, Scheck AC, Rakela J. (2005) Emerging evidence of hepatitis C virus neuroinvasion. AIDS. 19:S140-144.

9. Dispenzieri A, Kyle RA. (2005) Neurological aspects of multiple myeloma and related disorders. Best Pract Res Clin Haematol. 18:673-88.

10. Apartis E, Léger JM, Musset L, Gugenheim M, Cacoub P, Lyon-Caen O, et al. (1996) Peripheral neuropathy associated with essential mixed cryoglobulinaemia: a role for hepatitis C virus infection? J Neurol Neurosurg Psychiatry. 60:661-6.

\section{Submit your manuscript to a JScholar journal} and benefit from:

ฯ Convenient online submission

ฯ Rigorous peer review

- Immediate publication on acceptance

- Open access: articles freely available online

ब High visibility within the field

- Better discount for your subsequent articles

Submit your manuscript at http://www.jscholaronline.org/submit-manuscript.php 